https:/ /doi.org/10.18485/iipe_nsail.2020.ch7

Jelica GORDANIĆ ${ }^{1}$

\title{
POLOŽAJ NEVLADINIH ORGANIZACIJA U MEĐUNARODNOM PRAVU
}

Apstrakt: Rad razmatra osnovne teorijske dileme u pogledu međunarodnopravnog statusa nevladinih organizacija (NVO), njihov istorijski razvoj, položaj u Ujedinjenim nacijama i uticaj koji su ostvarile na razvoj međunarodnog prava. U tradicionalnom smislu, NVO se smatraju objektima a ne subjektima međunarodnog prava. Sagledavajući značaj i doprinos ovih nedržavnih aktera u pogledu razvoja međunarodnog prava i uspostavljanja međunarodnih institucija, autor zaključuje da je njihova uloga daleko veća od tradicionalnog shvatanja objekta međunarodnog prava. Njihov međunarodnopravni položaj nije regulisan, što im omogućava delovanje u svim oblastima međunarodnog prava $i$ međunarodne politike $\mathrm{u}$ kojima njihova uloga nije izričito zabranjena. Uprkos statusu koji se može opisati kao terra incognita, subjektivitet i uticaj nekih NVO se može uporediti sa međunarodnopravnim subjektivitetom međunarodnih organizacija. Rad ima za cilj da pokaže da se NVO udaljavaju od objekta međunarodnog prava i sve više stiču karakteristike koje se mogu pripisati subjektu međunarodnog prava.

Ključne reči: nevladine organizacije (NVO), međunarodno pravo, subjekt međunarodnog prava, nedržavni akter, Ujedinjene nacije.

\footnotetext{
${ }^{1}$ Naučni saradnik, Institut za međunarodnu politiku i privredu, jelica@diplomacy.bg.ac.rs;

Rad je nastao u okviru naučnoistraživačkog projekta "Srbija i izazovi u međunarodnim odnosima 2020. godine“, koji finansira Ministarstvo prosvete, nauke i tehnološkog razvoja Republike Srbije, a realizuje Institut za međunarodnu politiku i privredu tokom 2020. godine.
} 


\section{UVOD}

Pojam subjekta međunarodnog prava je jedan od pojmova oko koga se vode polemike. Tradicionalno, pod pojmom subjekta pravnog poretka podrazumeva se ,jedinka koja je sposobna da aktivno učestvuje $u$ određenom pravnom procesu, da bude neposredni nosilac prava i obaveza, sposobna da ostvari svoja prava kroz parničnu sposobnost. “2 Međunarodnopravni poredak se razvio na izrazito državocentričnoj osnovi. Samo i isključivo suverene države su posedovale snagu i sposobnost da ostvare prava na međunarodnom planu. Suverene države otuda predstavljaju izvorne, osnovne subjekte međunarodnog prava.

Razvojem nauke, tehnologije i napretkom procesa globalizacije javljaju se i drugi akteri, po nastanku, obliku i funkcionisanju različiti od država, ali sposobni da uđu u pravne odnose sa ostalim članovima međunarodne zajednice. U ovu grupu prvenstveno spadaju međunarodne organizacije kao dobrovoljne tvorevine država, osnovane međunarodnim ugovorima, koje mogu preduzimati akcije $u$ sopstveno ime, a ne isključivo $u$ ime država koje su ih osnovale. Za razliku od država koje raspolažu izvornom vlašću, autoritet međunarodnih organizacija zavisi od obima prava koje će države na njih preneti. Međunarodnopravni subjektivitet država se podrazumeva, dok međunarodne organizacije moraju dokazivati subjektivitet na osnovu osnivačkog ugovora. ${ }^{3}$

Praksa međunarodnog prava je sve bogatija, pa se pored država i međunarodnih organizacija javljaju i novi akteri koji mogu imati određene oblike međunarodnopravnog subjektiviteta - multinacionalne kompanije, pojedinci, nevladine organizacije itd. Pitanje: „Ko su relevantni akteri međunarodnog prava?" - u suštini je pitanje ko su subjekti međunarodnog prava. Akter koji nije subjekt međunarodnog prava može imati politički i pravni uticaj, ali će biti van pravnog sistema - i kao takav - irelevantan. ${ }^{4}$ Prema stavovima nekih teoretičara do 2025.

${ }^{2}$ Smilja Avramov, Milenko Kreća, Međunarodno javno pravo, Savremena administracija, Beograd, 2001, str. 73.

${ }^{3}$ Ibid., str. 74.

${ }^{4}$ Anna-Karin Lindblom, Non-Governmental Organisations in International Law, Cambridge University Press, New York, 2006, p. 85. 
godine države neće više biti jedini i najvažniji akteri na međunarodnoj sceni, i međunarodni sistem moraće da se prilagodi toj novoj realnosti. ${ }^{5}$

U tradicionalnom smislu, nedržavni akteri se smatraju objektima a ne subjektima međunarodnog prava. Imajući u vidu doprinos ovih aktera $\mathrm{u}$ pogledu razvoja međunarodnog prava, uspostavljanja međunarodnih institucija itd. jasno je da je njihov značaj i doprinos daleko veći od tradicionalnog viđenja objekta međunarodnog prava. Može se reći da postoji raskorak između de jure koncepta nedržavnih aktera koji se poistovećuju sa objektom međunarodnog prava, i de facto realnosti u kojoj se nedržavni akteri približavaju svojstvu subjekta međunarodnog prava. ${ }^{6}$

Rad razmatra nevladine organizacije (NVO) kao nedržavne aktere i ispituje njihovo svojstvo veoma aktivnog učesnika na međunarodnoj sceni - $u$ domenu međunarodne politike i međunarodnog prava. Šrokim opsegom delovanja NVO su izmenile međunarodno pravo i dale izuzetan doprinos njegovom razvoju, te su stekle određena prava i obaveze, što ih je udaljilo od svojstva objekta međunarodnog prava. Ove organizacije često učestvuju u različitim vidovima međunarodnih poslova, kao predstavnici civilnog društva, jer njihova uloga daje legitimitet i povećava stepen demokratičnosti. Njihov položaj u međunarodnom pravu je još uvek "terra incognita". ${ }^{7}$ Rad ima za cilj da pokaže da se NVO, svojim aktivnostima i položajem, udaljuju od objekta međunarodnog prava i sve više stiču karakteristike koje se mogu pripisati subjektu međunarodnog prava.

\footnotetext{
${ }^{5}$ Janne E. Nijman, "Non-state actors and the international rule of law: revisiting the 'realist theory' ofinternational legal personality", in: Math Noortmann and Cedric Ryngaert (Eds), Non-state actor dynamics in international law: from law-takers to lawmakers, Routledge, London and New York, 2010, pp. 91-124, p. 93 prema: NIC, Global Trends 2025: A Transformed World (November 2008), available online athttp://www.dni.gov/nic/NIC_2025_project.html

${ }^{6}$ Ibid., p. 95.

${ }^{7}$ Kerstin Martens, "Examining the (Non-)Status of NGOs in International Law", Indiana Journal of Global Legal Studies, Vol. 10, Issue 2, 2003, pp. 1-25, p. 24.
} 


\section{POJAM I RAZVOJ NEVLADINIH ORGANIZACIJA}

Nevladine organizacije su jedan od pojmova koji sa sobom nosi epitet kontroverznog, posebno $\mathrm{u}$ nekadašnjim komunističkim državama i državama trećeg sveta. NVO podrazumevaju „udruženja građana u koja se oni uključuju da bi ostvarili i zadovoljili neke svoje privatne i opšte društvene interese, motive i potrebe. Ta udruženja imaju status pravnog lica (institucionalizovana su), odvojena su od države, neprofitnog, nekomercijalnog i nepartijskog su karaktera, zasnovana na dobrovoljnom radu i ulaganju sredstava. “8 Predstavljaju „, organizacije od šireg društvenog značaja“ kojima se ne može osporiti „njihov politički značaj, odnosno širi društveni značaj, bez obzira na područje konkretne delatnosti. ${ }^{\text {" }}$

Pojam „nevladina organizacija“ najviše je u upotrebi u tranzicionim državama, kao i u državama Srednje i Istočne Evrope. ${ }^{10} \mathrm{Za}$ iste organizacije se koriste i pojmovi "organizacije civilnog društva", "nedržavni akteri“, ",treći sektor" $\mathrm{i}$ „udruženja građana“. Pravni osnov nastanka NVO i njihovog formiranja nalazi se "u pravu čoveka i građanina na slobodu udruživanja i delovanja sa drugim ljudima, koja zajedno sa osnovnim slobodama i pravima predstavlja početak razvoja modernog demokratskog društva. ${ }^{11}$

U svakodnevnom životu $\mathrm{NVO}$ se u očima laika uglavnom posmatraju kao nešto loše i poistovećuju se sa udruženjima koja su produkt hegemonije Zapada. NVO koje deluju na nacionalnim nivoima često se poistovećuju sa „trojanskim konjem koga hrane donori kako bi razvijao njihove političke interese“ ${ }^{\prime 2}{ }^{12}$ Suprotno ovim uverenjima, NVO

8 Žarko Paunović, Nevladine organizacije - Potreba ili zavera, Demokratska stranka/Istraživačko izdavački centar, Beograd, 2007, str. 6.

${ }^{9}$ Smilja Avramov, Milenko Kreća, Međunarodno javno pravo, Naučna knjiga, Beograd, 1986, str. 133.

${ }^{10} \mathrm{U}$ SAD se za isti tip organizacija koristi pojam "nonprofit sector", u Velikoj Britaniji „public charities“, a u Francuskoj „economie sociale“.

11 Žarko Paunović, „Neprofitne organizacije - prilog pojmovnom razjašnjenju“ , FPN Godišnjak, br. 6, 2011, str. 251-262, str. 255.

${ }^{12}$ Igor Pellicciari, "Feeding the Trojan horse: International aid policies in support to NGOs (1990-2015)”, in: Raffaele Marchetti (ed), Partnership in International PolicyMaking, Palgrave Macmilan, London, 2017, pp. 293-313, p. 309. 
nisu produkt hegemonije ni SAD niti ijedne zapadne države. NVO su nastajale i delovale podjednako kako na evropskom tako i na azijskom, afričkom i američkom kontinentu. ${ }^{13}$ Takođe, ni stereotipi o NVO kao pojavama novijeg datuma (od završetka II svetskog rata) nisu tačni. NVO su bile prisutne tokom istorije i njhovo delovanje vodi poreklo od ranog XVIII veka. Veliki broj međunarodnih NVO započinje aktivno delovanje po završetku II svetskog rata, pa se ova informacija često koristi kao stereotip o NVO kao produktu savremenog doba.

Međunarodne NVO predstavljaju ,institucionalni oblik međunarodne saradnje čiji subjekti nisu države, a kao osnivači se javljaju pojedinci, grupe, udruženja ili ustanove iz različitih zemalja $u$ najrazličitijim oblastima ljudskog delovanja, sa ciljem ostvarivanja zajedničkih interesa. ${ }^{\text {14 }}$ Pojam međunarodne nevladine organizacije prvi put se javlja u Rezoluciji 288B (X) Ekonomskog i socijalnog saveta Ujedinjenih nacija iz 1950. godine, prilikom razrađivanja odredbi Povelje u pogledu saradnje sa međunarodnim nevladinim organizacijama. Ovaj pojam je određen na odričan način - svaka međunarodna organizacija koja nije stvorena međuvladinim ugovorom smatraće se međunarodnom nevladinom organizacijom. Ova definicija je značajna jer sa sobom nosi jednu važnu osobinu NVO, a to je njihova stalnost i trajna organizovanost, po čemu se razlikuju od transnacionalnih političkih pokreta i transnacionalnih verskih organizacija. ${ }^{15}$ Pored međunarodnih nevladinih organizacija postoje i nacionalne NVO čija je delatnost u sklopu nacionalnog suvereniteta i odvija se po pravu države na čijoj teritoriji deluju.

${ }^{13}$ Thomas Davies, "The Historical Development of NGOs”, in: Aynsley Kellow, Hannah Murphy-Gregory (eds), Handbook of Researsh on NGOS, Edward Elgar Publishes, Chelthenham UK, Northampton,MA, USA, 2018, pp. 15-34, p. 15.

${ }^{14}$ Nemanja Danilović, „Međunarodne organizacije i njihova uloga subjekata međunarodnog prava", Megatrend Revija, Vol. 16, No. 2, 2019, pp. 95-114, p. 98.

${ }^{15}$ Ivan Gvozdenović, Ines Miladinović, "Međunarodne nevladine organizacije fenomen savremenog doba", Vojno delo, br. 4, 2015, str. 75-96, str. 80. 


\section{NVO kroz istoriju}

U cilju boljeg razumevanja prirode, delovanja i značaja NVO za pravno-politički poredak, neophodno je upoznati se sa njihovim razvojem. Obično se period XVIII veka uzima kao polazna tačka nastanka i razvoja prvih NVO. U periodu pre XVIII veka mnogobrojne $\mathrm{NVO}$ su delovale širom evropskog kontinenta $\mathrm{u}$ formi institucija religijskog karaktera, misionarskih udruženja, naučnih društava, bratstava i humanitarnih organizacija. Neka udruženja iz ovog perioda imala su transnacionalno članstvo, poput Kraljevskog društva iz Londona ili Društva slobodnih zidara, sa članstvom širom Evrope i atlantskog regiona. ${ }^{16}$

Period sredine i kasnog XVIII veka donosi novi talas $\mathrm{u}$ pogledu razvoja NVO. Tehnološki, ekonomski i društveni razvoj ovog perioda dovodi do transformacije $\mathrm{u}$ oblastima i pravcima delovanja NVO. Udruženja religijskog karaktera su i dalje prisutna, ali se usled promena koje je doneo tehnološki i ekonomski razvoj polje delovanja NVO širi sa religije na druge oblasti. Širi se i geografski opseg delovanja ovih organizacija, pa se ideje prenose iz evropskog na azijski kontinent i obrnuto. Istorijske prekretnice, poput francuske i američke revolucije, Bečki kongres i uspostavljanje međuvladinih tela stvaraju nove mogućnosti za međunarodno organizovanje NVO. Sekularne i humanitarne NVO šire delovanje u Evropi, Americi i Aziji. Na američkom kontinentu se afirmišu prve NVO za zabranu ropstva (poput Pensilvanijskog udruženja za razvoj zabrane ropstva), dok u Evropi i Aziji raste broj udruženja za pomoć utopljenicima. Ovaj vid NVO su bila udruženja medicinskih profesionalaca i za cilj su imala primenu medicinskih dostignuća u slučajevima spasavanja života. ${ }^{17}$

Period kasnog XIX veka karakterističan je po ekspanziji transnacionalnih NVO. Formiranje Svetske alijanse udruženja mladih hrišćana 1855. godine predstavlja prvi slučaj međunarodne federacije nacionalnih NVO. U ovom periodu dolazi do formiranja Organizacije

${ }^{16}$ Detaljnije videti kod: Thomas Davies, "The Historical Development of NGOs", op. cit., p. 16.

${ }^{17}$ Detaljnije videti kod: Ibid., pp. 17-18. 
Crvenog krsta, koja će u narednom periodu uspostaviti nove parametre $\mathrm{u}$ pogledu delovanja, aktivnosti ali i pravnog subjektiviteta međunarodnih NVO. NVO osnovane $\mathrm{u}$ ovom periodu dodatno šire opseg delovanja na nova pitanja - prava žena, zaštitu životinja, sport, uska pitanja struke itd. Zanimljivo je istaći da dve NVO osnovane $u$ ovom period - Međunarodni olimpijski komitet i Međunarodni savet žena, postoje i dan-danas. Transnacionalne NVO se u velikom broju formiraju i u Aziji i Latinskoj Americi. ${ }^{18}$

Period XX veka karakterističan je po novim oblicima saradnje sa NVO. Prvi međunarodni ugovor koji je predviđao učešće i saradnju sa NVO bila je konvencija o osnivanju Međunarodnog instituta poljoprivrede 1905. godine u Rimu. U konvenciji se, kao jedna od dužnosti Instituta, navodi „podnošenje na odobrenje vladama, ukoliko za to postoji potreba, mera za zaštitu opštih interesa farmera i za poboljšanje njihovog položaja, nakon što su iskorišćeni svi potrebni izvori informisanja u koja spadaju međunarodni i drugi poljoprivredni kongresi ili kongresi nauka koji se odnose na poljoprivredu, poljoprivredna društva, akademije, naučna tela itd. "19 Prema ovoj odredbi, kongresi i društva su određeni kao izvori informisanja u procesu donošenja odluka na međudržavnom nivou. Ovu praksu nastavlja i Međunarodna organizacija rada uključujući službenike NVO u svoje aktivnosti.

Saradnju sa NVO predviđala je i Povelja Društva naroda u članu 25 koji navodi da su „članice Društva naroda saglasne da podstiču i razvijaju saradnju sa ovlašćenim dobrovoljnim nacionalnim organizacijama Crvenog krsta koje za cilj imaju poboljšanje zdravlja, sprečavanje bolesti i ublažavanje patnji širom sveta. ${ }^{20}$ Tokom kratkotrajnog funkcionisanja Društva naroda, ova organizacija aktivno

${ }^{18}$ Detaljnije videti kod: Ibid., pp. 17-19.

${ }^{19}$ Convention on the International Institute ofAgriculture, Convention signed at Rome June 7,1905, Article 9 (f).

${ }^{20}$ The Covenant of the League of Nations (Including Amendments adopted to December, 1924), Article 25. Internet: https:/ / avalon.law.yale.edu/20th_century/ leagcov.asp 09/07/2020. 
je sarađivala sa nacionalnim organizacijama Crvenog krsta, dok je Liga društava Crvenog krsta (današnja Međunarodna federacija društava Crvenog krsta i Crvenog polumeseca) imala važnu ulogu u izradi nacrta međunarodnih ugovora i blisko sarađivala sa državama članicama Društva naroda. Predstavnici NVO su učestvovali na konresima Društva naroda i u specijalnim komitetima koji su se bavili specifičnim pitanjima poput trgovine ljudima.

U godinama nakon završetka II svetskog rata, brojne NVO su dale veliki doprinos procesu dekolonizacije, putem razvoja antikolonijalnih normi, ali i razvijanjem taktika otpora protiv kolonijane vlasti. Nastajanjem regionalnih organizacija, nastaju i nove prilike za NVO. U ovom periodu primetan je nastanak NVO na regionalnoj osnovi, kao izraz mogućnosti saradnje sa novoformiranim regionalnim organizacijama. NVO se tokom XX veka brzo prilogođavaju ekonomskoj i političkoj situaciji, prate glavne pravne i političke trendove i deluju u skladu sa svim razvojnim tendencijama. Sa porastom broja transnacionalnih kompanija, aktivnosti NVO su usmerene ka njima i ukazivanju na lošu korporativnu politiku. Ovaj fenomen raskrinkavanja transnacionalnih kompanija od strane NVO teoretičari nazivaju politikom izvan nivoa države. ${ }^{21}$

Poslednju dekadu XX veka obeležilo je formiranje koalicije transnacionalnih NVO u cilju sklapanja sporazuma o važnim pitanjima. Najuspešnije u ovom poduhvatu bile su Međunarodna kampanja za zabranu mina i Koalicija za međunarodni krivični sud. Inicijative su imale velikog uspeha i izuzetno su doprinele usvajanju Konvencije o minama iz Otave 1997. godine, kao i usvajanju Rimskog statuta Međunarodnog krivičnog suda. ${ }^{22}$

Međutim, ni kritike na račun NVO nisu izostale. Jedan deo teoretičara, kao i vlade mnogih država, dovode u pitanje legitimitet,

${ }^{21}$ Christine Bakker, Luisa Vierucci, „Introductions: normative or pragmatic definition of NGOs", in: Pierre-Marie Dupuy, Luisa Vierucci (ed), NGOs in International Law: Efficiency in Flexibility?, Edward Elgar Publishing, Cheltenham, UK and Northampton, MA. (USA), 2009, pp. 1-20, p. 4.

${ }^{22}$ Detaljnije videti kod: Thomas Davies, "The Historical Development of NGOs", op. cit., p. 26. 
integritet i reprezentativni karakter $\mathrm{NVO}$, smatrajući da su ove organizacije van uređenog sistema države, sa sopstvenim interesima i ciljevima. Mnoge NVO imaju sedište u razvijenim zapadnim državama, te se kritičari pitaju da li ove organizacije razvijaju interese određene grupe država ili interese celog čovečanstva, i da li imaju realne kapacitete da vrše ulogu koja im je poverena. ${ }^{23}$

Uspon tehnologije u XXI veku i razvoj društvenih mreža omogućio je nove aspekte delovanja nedržavnih aktera - pojedinaca i NVO. Društvene mreže su omogućile prave revolucije, poput Arapskog proleća. Transnacionalne NVO zajedno sa tehnološkom revolucijom i masovnim medijima „ruše tradicionalne granice diplomatske prakse. ${ }^{24}$

\section{KONSULTANTSKI STATUS NVO U UJEDINJENIM NACIJAMA}

Imajuću u vidu uspešnu saradnju Društva naroda i nevladinog sektora, predstavnici mnogih NVO su uložili dosta lobirajućih napora da se saradnja sa NVO sektorom nastavi i u drugoj univerzalnoj organizaciji - Ujedinjenim nacijama.

Napori su urodili plodom i za rezultat imaju član 71 Povelje UN koji predviđa da „Ekonomski i socijalni savet može da zaključi potrebne sporazume radi konsultovanja sa zainteresovanim nevladinim organizacijama zainteresovanim za pitanja koja ulaze $u$ okvir njegove nadležnosti.“ U nedostatatku pravila međunarodnog prava koja se odnose na NVO član 71 Povelje služi „de facto kao povelja za aktivnosti NVO. ${ }^{25}$ Imajući u vidu tradiciju konsultantske saradnje sa NVO u periodu pre 1945. godine, formulacija člana 71 Povelje UN je "pre

${ }^{23}$ Paul Wapner, "Civil Society“, in: Thomas G. Weiss, Sam Daws (eds), The Oxford Handbook on the United Nations, Oxford University Press, Oxford, 2007, pp. 254264, p. 261.

${ }^{24}$ Mari Fitzduff, Cheyanne Church, "Stepping up to the table: NGOs Strategies for Influencing policy on conflics issues", in: Mari Fitzduff, Cheyanne Church (eds), NGOs at the Table: Strategies for Influencing Policies in Areas of Conflict, Rowman \& Littlefield Publishers, Landham, MD, 2004, pp. 2-22, p. 10.

${ }^{25}$ Steve Charnovitz, Nongovernmental Organizations and International Law, The American Journal of International Law, Vol. 100, No. 2 (Apr., 2006), pp.348-372, p. 357. 
očekivanog, nego epohalnog karaktera. ${ }^{26}$ UN Komitet za NVO je zadužen za akreditaciju NVO i dodeljivanja konsultantskog statusa. Ovo telo, uspostavljeno 1946. godine, za rad je odgovorno Ekonomskom i socijalnom savetu.

Formalni sporazumi za ostvarivanje konsultantskog statusa NVO menjani su nekoliko puta - 1950, 1968, 1996. i 2004. godine.

„Pravilo za NVO iz 1950. godine“ (Rezolucija Ekonomskog i socijalnog saveta $288 \mathrm{~B}(\mathrm{X})$ od 27 . februara 1950 . godine) predviđa da NVO bude „priznata“ i da "predstavlja značajan deo organizovanih lica u određenoj oblasti u čijoj sferi deluje“.

Pravilo za NVO iz 1968. godine (Rezolucija Ekonomskog i socijalnog saveta 1296 (XLIV) od 25. maja 1968.) predviđa da NVO ,treba da bude priznata u oblasti u kojoj deluje ili da bude reprezentativnog karaktera". Izmena uvedena 1968. godine je blaža od rešenja predviđenim prethodnom rezolucijom koja je zahtevala i element priznatosti i reprezentativnosti. Pravilo iz 1968. godine zahteva i da NVO ima demokratski usvojen ustav, reprezentativnu strukturu, da poseduje odgovarajuće mehanizme odgovornosti prema svojim članovima koji imaju kontrolu na njenim aktivnostima putem glasanja i drugih odgovarajućih demokratskih i transparentnih načina odlučivanja. Ciljevi i principi NVO moraju biti u skladu sa Poveljom i ciljevima UN i NVO mora razvijati rad UN. ${ }^{27}$

Pravilo za NVO iz 1996. godine predviđa da Komitet za NVO Ekonomskog i socijalnog saveta može oduzeti status konsultanta NVO ukoliko one zloupotrebljavaju svoj status vršeći aktivnosti suprotne Povelji i ciljevima UN, ukoliko ostvaruju prihode od međunarodnih kriminalnih aktivnosti i ako $u$ predhodne tri godine nisu dale nikakav pozitivan doprinos radu UN, a posebno Ekonomskom i socijalnom savetu ili njegovim komisijama i drugim pomoćnim organima. ${ }^{28}$ Pravilom iz 1996. godine uspostavljaju se i tri kategorije konsultantskog statusa:

\footnotetext{
${ }^{26}$ Ibid., p. 358.

${ }^{27}$ Detaljnije videti kod: Ibid., pp. 358-359.

${ }^{28}$ Resolution 1996/31 Consultative Relationship between the United Nations and non-governmental organizations, ECOSOC. Art. 57 (a, b, c). Internet: https:/ / www.un.org/esa/coordination/ngo/Resolution_1996_31/index.htm 09/07/2020.
} 
- Kategorija I obuhvata organizacije demokratskog kapaciteta koje doprinose ekonomskim i socijalnim ciljevima UN.

- NVO koje spadaju u Kategoriju II se bave specifičnim oblastima nadležnosti Ekonomskog i socijalnog saveta.

- Organizacijama iz Kategorije III nedostaje konsultantski status, a one povremeno daju doprinos radu UN tela.

Konačno, Kardozo izveštaj iz 2004. godine pod nazivom „Mi, narodi: civilno društvo, Ujedinjene nacije i globalno upravljanje“, navodi da „uspon civilnog društva predstavlja jedno od najvećih dostignuća našeg vremena. Globalno upravljanje više nije samo u domenu Vlada. Povećano učešće i uticaj nedržavnih aktera poboljšava demokratiju i oblikuje multilateralizam. ${ }^{29}$

Do sada je oko hiljadu NVO steklo konsultantski status prema odredbi člana 71 Povelje, a slični sporazumi se zaključuju i u okviru specijalizovanih agencija UN.

Šta podrazumeva konsultantski status NVO u Ujedinjenim nacijama i kakve privilegije sa sobom nosi? Predstavnici NVO sa konsultantskim statusom mogu aktivno ili u svojstvu posmatrača učestvovati na sastancima Ekonomskog i socijalnog saveta i njihov memorandum može cirkulisati kao dokument UN. NVO najvišeg konsultantskog statusa mogu podnositi predloge za agendu Ekonomskog i socijalnog saveta. ${ }^{30}$ Pored toga, NVO sa konsultantskim statusom prikupljaju informacije, savetuju države članice, prikupljaju podršku Vlada i građana država članica za politiku UN, dostavljaju informacije organizaciji o stanju na terenu u pogledu operacija važnih za UN i na neki način predstavljaju bazu znanja i informisanja za odluke UN i međudržavne pregovore. Sve ove aktivnosti se realizuju na UN forumima, konferencijama, sastancima

${ }^{29}$ We the people: CivilSociety, the United Nations and Global Governance: Report of the Panel of Eminent Persons on United Nations - Civil Society Relations, A/58/817, 7 June 2004. Internet: https:/ / www.unog.ch/80256EDD006B8954/ (httpAssets)/09916F545454357BC1256F5C005D4352/\$file/ A-58-817.pdf 10/07/2020.

${ }^{30}$ Detaljnije videti kod: Boleslaw Adam Boczek, International Law: A Dictionary, Scarecrow Press, Lanham, Maryland, 2005, p. 76. 
supsidijarnih tela, službenicima Sekretarijata, Odeljenju za javno informisanje itd.

Status konsultata je omogućio NVO da uzmu učešće u velikom opsegu delatnosti UN. Tako npr. NVO koje se bave pitanjima osoba sa invaliditetom, pitanjima životne sredine, pravima deteta i sl. uzimaju učešće u radu na nacrtima ugovora i oblikuju jezik ugovora. NVO imaju veoma značajnu $u \log u \mathrm{u}$ realizaciji UN aktivnosti $\mathrm{u}$ pogledu humanitarnih, razvojnih i aktivnosti u pogledu životne sredine. NVO pružaju operativnu podršku raznovrsnim aktivnostima koje sprovode pomoć prilikom izbora, post-konfliktna rekonstrukcija, nadzor nad sprovođenjem ugovora. Mnoge NVO su uključene u UN programe za podršku stanovništvu pogođenom nasilnim konfliktima ili prirodnim katastrofama jer poseduju znanje, opremu i osoblje obučeno za humanitarne krize, te iz tog razloga predstavljaju najbolji izbor za ovaj vid UN aktivnosti. U ovoj vrsti poslova NVO su sarađivale sa Svetskom zdravstvenom organizacijom, UNHCR-om, UNICEF-om i mnogim drugim specijalizovanim agencijama UN. ${ }^{31}$

Iz navedenih primera vidimo da je saradnja NVO sa UN zaista razgranata, sa mnogobrojnim potencijalima za još širi opseg saradnje. U „Milenijumskoj deklaraciji“ tadašnji generalni sekretar UN Kofi Anan istakao je da jačanje odnosa izneđu Ujedinjenih nacija i nedržavnih aktera predstavlja jedan od najvažnijih ciljeva njegovog mandata i da je neophodno pružiti široke mogućnosti NVO i drugim nedržavnim akterima da daju svoj puni doprinos kroz saradnju sa Ujedinjenim nacijama. ${ }^{32}$

Panel formiran 2002. godine, u cilju razrade Milenijumske deklaracije, razmatrao je pitanje saradnje NVO i Ujedinjenih nacija, imajući u vidu reformisanje tog odnosa i pronalazak načina pomoću kojeg će njihova saradnja biti podignuta na viši i efikasniji nivo. Panel je predložio tri smernice u pogledu osnaživanja pravnog statusa NVO i njihovih postupaka akreditacije:

${ }^{31}$ Detaljnije videti kod: Paul Wapner, "Civil Society", op. cit., pp. 258-260.

${ }^{32}$ Report of the Secretary General, We the Peoples: The Role of the United Nations in the Twenty First Century, U.N. Doc. A/54/2000 (2000). 
- učešče NVO u radu glavnih organa Ujedinjenih nacija treba da bude prošireno uspostavljanjem konsultantskog statusa NVO u okviru Generalne skupštine i formalizovanjem postojeće prakse konsultacija sa Savetom bezbednosti;

- proces akreditacije treba da bude pojednostavljen i depolitizovan, posebno uspostavljanjem zajedničkog sistema akreditacije za sve UN forume;

- samoregulacija, koja treba da se razvija priznavanjem širih prava participacije mrežama organizacija civilnog društva i ohrabrivanjem NVO da izrađuju nacrte kodeksa sopstvenih pravila ponašanja. ${ }^{33}$

\section{NVO I MEĐUNARODNO PRAVO}

Poslednjih nekoliko decenija nevladine organizacije kao nedržavni akteri nisu bile $\mathrm{u}$ velikoj meri izučavane od strane teoretičara. Intenzivnije izučavanje uticaja NVO na tokove međunarodnog prava i međunarodne politike je pojava relativno novijeg datuma.

Mnoge države umanjuju ulogu i značaj NVO u procesu razvoja i usavršavanja međunarodnog prava. Veliki broj teoretičara se ne slaže sa ovim stavom smatrajući da su NVO „u prošlosti imale, a i dalje imaju, važnu ulogu u pomeranju granica međunarodnog prava putem lobiranja na nacionalnom, regionalnom i međunarodnom nivou, pohađajući pregovore, podnoseći pisane podneske $u$ slučajevima $u$ kojima je to moguće, i izrađujući alternativne nacrte međunarodnih ugovora na globalnim forumima. ${ }^{\text {"34 }}$ Veliki deo teorije smatra da je uticaj NVO u procesu razvoja međunarodnog prava činjenica koja se ne može poreći.

${ }^{33}$ Emanuele Rebasti and Luisa Vierucci, "Legal Status for NGOs in Contemporary International Law?", The paper don the outcomes of the Workshop on 'A Legal Status for NGOs in Contemporary International Law? A Contribution to the Debate on "Non-State Actors" and Public International Law at the Beginning of the Twenty-First Century, pp. 1-19, p. 10. Internet: https://esil-sedi.eu/wpcontent/uploads/2018/04/VierucciRebasti-1.pdf 11/08/2020.

${ }^{34}$ Prue Taylor, An Ecological Approach to International Law: Responding to the Challenges of climate change, Routledge, London and New York, 1998, p. 325. 
Njihovo učešće je bez sumnje izmenilo iz korena sam proces nastanka pravnih normi, razbilo mit o premoći država u ovoj oblasti i pokazalo da se neslaganje sa stavovima država može preneti na međunarodni nivo. Aktivno učešće NVO je „unelo element demokratičnosti u područje stvaranja međunarodnog prava, koje nije poznato po demokratičnosti. “35

NVO kao nedržavni akteri učestvuju u procesu stvaranja, razvoja i primene pravila međunarodnog prava. One predstavljaju nosioce novih ideja, činioce koji održavaju fokus, pritisak i efikasna sredstva akcije u međunarodnom pravnom sistemu. One, pored toga što povećavaju transparentnost, državi nude i alternativne, drugačije stavove i na taj način vrše uticaj na državu u pogledu nastajanja i razvoja međunarodnog prava. Na neki način, NVO nude širu perspektivu i sagledavanje potencijalnih problema iz više uglova, pa na taj način vrše korekciju stavova države i omogućuju više neutralnosti.

NVO su dale veliki doprinos u pogledu razvoja određenih grana prava - ljudskih prava, prava životne sredine, međunarodnog humanitarnog prava itd. Bez uloge NVO ove grane prava verovatno ne bi imale oblik koji imaju danas. Naravno, o uticaju i učešću NVO na svaku od ovih grana prava se može napisati poseban rad. Na ovom mestu ćemo preneti zapažanja autora u pogledu uloge NVO u slučaju razvoja prava životne sredine, a koje se može preneti i na ulogu NVO u pogledu razvoja drugih grana prava. Američki profesor A. Dan Tarlok smatra da NVO, uprkos svom položaju "moći bez pravnog statusa“, imaju sposobnost da utiču na politiku multinacionalnih organizacija i direktno utiču na izbore koji su tradicionalno rezervisani za pojedinačne suverene države prema pravilima međunarodnog prava. One vrše stvarnu moć u međunarodnoj zajednici. U okviru prava životne sredine, njihov uticaj je porastao od učešća u razvoju ekoloških standarda ponašanja do uticaja na formulisanje i primenu ekoloških politika $u$ okviru međunarodnih organizacija i nacionalnih država. ${ }^{36}$

${ }^{35}$ Barry E. Carter, Allen S. Weiner, Duncan B. Hollis, International Law, Walters Kulwer, New York, 2018, p. 151.

${ }^{36}$ A. Dan Tarlock, "The Role of Non-Governmental Organizations in the Development of International Environmental Law", Chicago-Kent Law Review, Vol. 68, Issue 1, 1992, pp. 61-76, p. 65. 
Rio Deklaracija i Agenda 21 ističu važnost partnerstva sa NVO. Agenda 21 navodi da "organizacije sistema Ujedinjenih nacija i druge međuvladine organizacije i forumi, bilateralni programi i privatni sektor, treba da obezbede povećanu finansijsku i administrativnu podršku za nevladine organizacije i njihove organizovane mreže, posebno za one $u$ zemljama u razvoju, doprinoseći nadzoru i evaluaciji programa Agende 21 i obezbeđujući treninge za nevladine organizacije... kako bi ojačale njihovu partnersku ulogu u implementaciji programa. ${ }^{\text {" } 37}$

Generalno, u procesu stvaranja pravila međunarodnog prava NVO mogu učestvovati na tri načina:

- identifikovanjem problema međunarodnog karaktera putem međunarodnih pravnih instrumenata i lobiranjem na države i ostale nedržavne aktere da podrže incijativu za zaključenje ugovora $u$ okviru UN ili van sistema UN;

- formalnim učešćem u procesu nacrta ugovora;

- dodeljivanjem formalne uloge NVO ugovornim odredbama. ${ }^{38}$

Nedržavni akteri učestvuju kao posmatrači u radu i aktivnostima međunarodnih organizacija. Ovo pravo im je zagrantovano odredbama ugovora, pravilima procedure ili kao rezultat prakse. OSPAR konvencija, iz 1992. godine, po prvi put uključuje ugovorne odredbe o posmatračima koje ne prave razliku između država, međunarodnih vladinih organizacija $\mathrm{i}$ nevladinih organizacija $\mathrm{u}$ pogledu uslova sticanja posmatračkog statusa. ${ }^{39}$ Nakon dobijanja posmatračkog statusa, svaki posmatrač ima jednaka prava - da predoči komisiji bilo kakvu informaciju ili izveštaje relevantne za ciljeve Konvencije, ali nijedan posmatrač nema pravo glasa.

${ }^{37}$ United Nations Conference on Environment \& Development Rio de Janerio, Brazil, 3 to 14 June 1992 AGENDA 21. Internet: https:/ / sustainabledevelopment. un.org/content/documents/Agenda21.pdf 18/08/2020.

${ }^{38}$ Barbara K. Woodward, The Role of International NGOs: An Introduction , Willamette Journal of International Law and Dispute Resolution, Vol. 19, Issue 2 (2011), pp. 203-231, p. 216-217.

${ }^{39}$ Convention for The Protection of the Marine Environment of the North-East Atlantic, Article 11(1). Internet: https:/ / www.ospar.org/site/assets/files/1290 /ospar_convention_e_updated_text_in_2007_no_revs.pdf 18/07/2020. 
Arhus konvencija iz 1989. je još blagonaklonija prema NVO i omogućava im učešće na sastancima i nominovanje kandidata za implementacioni komitet Konvencije. ${ }^{40}$

Pored uticaja koji imaju na razvoj međunarodnog prava, NVO imaju moć i da spreče usvajanje nekih međunarodnih ugovora. To se desilo npr. u slučaju pregovora o Multilateralnom sporazumu o investicijama u okviru OECD-a tokom devedesetih godina XX veka. Usled tajnih pregovora u pogledu odredbi ugovora koje su imale za cilj zaštitu prava stranih investitora i ograničenja mogućnosti vlada da usvajaju zakone od javnog interesa, NVO su kampanju protiv ugovora usmerile ka građanima i vladama putem podizanja svesti i edukacije u pogledu najvažnijih ugovornih odredbi. Do trenutka kada su pregovarači OECDa prihvatili konsultacije sa NVO, atmosfera je već bila previše naelektrisana za konstruktivne razgovore. Usled pritiska NVO pregovori o Multilateralnom sporazumu o investicijama su stali, a ovaj primer se često navodi u literaturi kao jedan od najbržih poraza ugovornog prava koji je usledio inicijativom NVO. ${ }^{41}$

NVO su važni akteri u slučajevima primene međunarodnog prava. $\mathrm{U}$ mnogobrojnim slučajevima one mogu pomagati pojedincima $u$ podnošenju predstavki međunarodnim pravosudnim organima, mogu same podnositi tužbe i obezbeđivati neophodne informacije međunarodnim telima (što neće biti učinjeno od strane države). U obezbeđivanju informacija međunarodnim telima najviše se ističu NVO koje se bave ljudskim pravima. Ove organizacije kontinuirano prikupljaju informacije o kršenju ljudskih prava i sačinjavaju predloge $u$ pogledu razvoja i primene pravila međunarodnih ljudskih prava. $\mathrm{Na}$ ovaj način one skreću pažnju i utiču na javno mnjenje, dok istovremeno vrše pritisak na države i međuvladine organizacije u pogledu loše prakse i potrebe za nastajanjem novih standarda. Predstavnici NVO su direktno

${ }^{40}$ Convention on access to information, public participation in decision-making and access to justice in environmental matters, done at Aarhus, Denmark, on 25 June 1998, Article 10(5). Internet: https://www.unece.org/fileadmin/DAM/env /pp/documents/cep43e.pdf 18/07/2020.

${ }^{41}$ Detaljnije videti kod: Barry E. Carter, Allen S. Weiner, Duncan B. Hollis, International Law, op. cit., p. 151. 
uključeni u izradu nacrta brojnih međunarodnih ugovora. Tako su npr. eksperti iz Amnesty International i drugih NVO učestvovali u izradi Konvencije protiv torture i drugih surovih, neljudskih i ponižavajućih kazni ili postupaka i Konvencije o pravima deteta. ${ }^{42}$

Prisustvo NVO je važno u slučaju nadzora primene ugovora o ljudskim pravima. Veliki broj ugovora o ljudskim pravima ne sadrži odredbe o učešću $\mathrm{NVO}$, već se njihovo učešće razvija kroz praksu nadzornih organa ugovora. Konvencija o pravima deteta omogućava saradnju sa NVO i u članu 45 navodi da „Komitet može pozvati specijalizovane agencije, UNICEF i druga kompetentna tela koja smatra pogodnim u cilju pružanja stručnih saveta o implementaciji Konvencije u područjima koja spadaju u područje njihovih nadležnosti. “ Komitet za prava deteta organizuje prisustvo NVO na sastancima pred-sesijskih radnih grupa, na kojima planira rad za sledeće zasedanje. Ovo rešenje omogućava NVO da sačine dnevni red pitanja o kojima će svaka država morati da izveštava Komitet. Mnogi teoretičari smatraju da prisustvo NVO čini značajnu razliku u kvalitetu nadzora ugovora o ljudskim pravima. Nadzorni odobri su u mogućnosti da postavljaju znatno konkretnija i specifičnija pitanja u slučajevima u kojima postoji uključenost $\mathrm{NVO}$, dok je ovaj proces mnogo manje produktivan i uspešan bez njihovog prisustva. ${ }^{43}$

Međunarodna ljudska prava podrazumevaju i žalbene postupke koji omogućuju pojedincima ili grupama da podnose predstavke protiv država zbog kršenja ljudskih prava. Mnoge međunarodne konvencije o ljudskim pravima predviđaju da samo oštećeni može pokrenuti postupak pred određenim međunarodnim sudom za zaštitu ljudskih prava, bez mogućnosti da postupak pokrene NVO. Ovo se posebno odnosi na Evropski sud o ljudskim pravima. Za NVO značajna novost u pogledu međunarodnopravnog subjektiviteta dolazi sa afričkog

\footnotetext{
${ }^{42}$ Kerstin Martens, "Examining the (Non-)Status of NGOs in International Law", Indiana Journal of Global Legal Studies, vol. 10, no. 2, Spring 2003, pp. 1-24, p. 9.

${ }^{43}$ Holly Cullen \& Karen Morrow, "International civil society in international law: The growth of NGO participation", Non-State Actors \& International Law, No. 1, Vol. 1, 2001, pp. 7-39, p. 19.
} 
kontinenta. Naime, od 2019. godine devet od 30 država potpisnica Protokola Afričke povelje o ljudskim pravima i pravima naroda o uspostavljanju Afričkog suda za ljudska prava i prava naroda potpisalo je deklaraciju kojom se dozvoljava pojedincima i NVO da pokrenu postupak pred Afričkim sudom.

\section{NVO KAO AMICUS CURIAE}

NVO doprinose međunarodnom pravosuđu putem statusa amicus curiae. Najvažniji međunarodni sudovi su razvili procedure koje omogućuju NVO da ostvare status prijatelja suda. NVO su se posebno istakle $\mathrm{u}$ pogledu podnošenja informacija $\mathrm{u}$ svojstvu amicus curiae Evropskom sudu za ljudska prava, ali i Međunarodnom krivičnom sudu za bivšu Jugoslaviju i Međunarodnom tribunalu za Ruandu itd. U svojstvu amicus curie NVO nisu još uvek imale saradnju sa Međunarodnim sudom za pravo mora. Svojstvo NVO kao amicus curiae značajno je iz više razloga. S jedne strane, NVO se smatraju ekspertima za oblasti prava kojima se bave. S druge strane, NVO karakteriše nezavisnost, te $\mathrm{u}$ izradama svojh brifinga ne zavise od države, međunarodne organizacije ili bilo kog drugog aktera. Njihovi stavovi i njihov doprinos se mogu uzeti kao neutralni, relevantni i pouzdani.

Međunarodni sud pravde nije otvoren za saradnju sa NVO, iako se značajan pomak odigrao 2004. godine kada dolazi do usvajanja Smernica za praksu XII. Smernice omogućuju da u savetodavnom postupku, kada NVO podnese izjavu ili dokument na sopstvenu inicijativu, ti dokumenti budu smešteni na određenom mestu u Palati mira. Dokumenti neće biti smatrani delom slučaja, ali će biti dostupni svakoj državi ili međunarodnoj organizaciji kao i sve javne informacije. ${ }^{44}$

Učešće NVO kao amicus curiae u pogledu Evropskog suda za ljudska prava važno je iz više razloga:

- poboljšava položaj podnete predstavke oštećenog dajući spoljnu i objektivnu podršku iznetim argumentima;

${ }^{44}$ Steve Charnovitz, "Nongovernmental Organizations and International Law", op. cit., p. 353. 
- isticanje javnih interesa koji nisu obuhvaćeni predstavkom;

- doprinose razvoju međunarodnog prava;

- skreće se pažnja široj javnosti. ${ }^{45}$

Jedan od najpoznatijih slučajeva intervencije NVO u svojstvu amicus curiae predstavlja slučaj Soering protiv Ujedinjenog Kraljevstva iz 1989. godine. U ovm slučaju, SAD su tražile izručenje nemačkog državljanina od Ujedinjenog Kraljevstva. Soering je bio optužen za ubistvo, i u slučaju izručenja SAD suočavao se sa smrtom kaznom. Intervencijom Amnesty International, u svojstvu amicus curiae, Evropski sud za ljudska prava je doneo presudu kojom se odbija izručenje Soeringa Sjedinjenim Američkim Državama, a smrtnu kaznu smatra nehumanom koja kao takva narušava Evropsku konvencija o ljudskim pravima.

U pogledu statusa NVO kao amicus curiae postoje različita mišljenja. U intervjuu koji je rađen sa sudijama Evropskog suda za ljudska prava, mnoge sudije su istakle da brifinzi podneti od strane NVO predstavljaju stavove i tumačenja NVO koje ih podnose, dok neke sudije navode da brifinzi NVO kao amicus curiae predstavljaju „ništa više od akta uglađenosti. Sud pokušava da ojača NVO koje se bave ljudskim pravima i njihovu ulogu i iz tog razloga u presudama priznaje njihove izveštaje. ${ }^{\text {"46 }}$

Kada se govori o NVO, nemoguće je ne pomenuti Međunarodni komitet Crvenog krsta (MKCK). MKCK osnovao je Švajcarac Henri Dunant 1873. godine prema švajcarskom pravu. Svajcarska priznaje međunarodnopravni subjektivitet MKCK. Interesantno je na ovom mestu pomenuti slučaj Simić pred Međunarodnim krivičnim sudom za bivšu Jugoslaviju. U slučaju Simić postavilo se pitanje da li bi zaposleni u MKCK mogao da svedoči o činjenicama koje su se odigrale za vreme službe u organizaciji. Ono što je od posebne važnosti za nevladine

${ }^{45}$ Marco Frigessi di Rattalma, "NGOs before the European Court of Human Rights: Beyond Amicus Curiae Participation", in: Tullio Treves, Alessandro Fodella et al. (eds), Civil Society, International Courts and Compliance Bodies, Asser Press, The Hague, 2005, pp. 57-67, p. 58.

${ }^{46}$ Kanstantsin Dzehtsiarou, European Consensus and the Legitimacy of the European Court of Human Rights, Cambridge University Press, Cambridge, 2015, p. 98 . 
organizacije u ovom slučaju jeste činjenica da je Veće primetilo da je MKCK jedinstven entitet i institucija koja poseduje međunarodnopravni subjektivitet, jer su ga države prećutno priznale kao subjekt prava. ${ }^{47}$ MKCK po mnogim svojim karakteristikama predstavlja NVO koja se po svom statusu približava međunarodnim organizacijama. Svakako, nije i jedina. U ovom kontekstu treba pomenuti i Međunarodni olimpijski komitet i Svetsku antidoping agenciju.

\section{NVO I MEĐUNARODNOPRAVNI SUBJEKTIVITET}

Pored aktivne uloge NVO u svetskim političkim tokovima i doprinosu koji daju u pogledu razvoja međunarodnog prava, funkcije i karakteristike NVO kao aktera na međunarodnoj sceni još uvek nisu u potpunosti jasno definisane. U očima međunarodnog prava NVO nisu subjekti međunarodnog prava. Prema klasičnim shvatanjima, to svojstvo pripada državama i međunarodnim organizacijama. Ne postoji nijedna pravna norma koja reguliše pravni subjektivitet NVO i njihova prava i obaveze u okviru međunarodnog prava.

Nepostojanje jasno određenog statusa NVO nosi sa sobom mnogo nedostataka, ali takođe ima i određenih prednosti. NVO koriste neregulisani pravni status kao mogućnost za preduzimanje različitih aktivnosti u međunarodnoj sferi. Uz nepostojanje jasnih uslova, pravila i kriterijuma, NVO se pruža prilika da učestvuju u mnogim međunarodnim aktivnostima iz kojih nisu eksplicitno isključene. ${ }^{48}$

Neosporna je činjenica da su NVO subjekti unutrašnjeg prava, prava države u kojoj su osnovane. Imajući u vidu da mnoge nevladine organizacije vrše aktivnosti i van teritorije države osnivanja, dolaze $u$ realnu mogućnost sukoba prava, pa čak i nemogućnosti da održavaju svoj pravni status u svim državama u kojima deluju. $S$ druge strane, ne može

${ }^{47}$ Videti detaljnije kod: William Thomas Worster, Relative International Legal Personality Of Non-State Actors, Brooklyn Journal of International Law, Vol. 42, No. 1, 2016, pp. 207-272, p. 245-247.

${ }^{48}$ Kerstin Martens, "Examining the (Non-)Status of NGOs in International Law", op. cit., p. 2. 
se poreći da su određene NVO stekle svojstvo pravnog subjektiviteta, zaključujući ugovore sa međunarodnim organizacijama ili kao rezultat specifičnih ugovornih odredbi. Mnoge NVO deluju na međunarodnom planu i mogu imati veliki uticaj na pravo i politiku neke države. Naravno, uticaj NVO se ne može garantovati niti se može na efikasan način izmeriti. Države i međunarodne organizacije su bez sumnje tradicionalni, osnovni, najvažniji subjekti međunarodnog prava. $S$ druge strane, uloga države postepeno opada i gubi na značaju, dok istovremeno nedržavni akteri (uključujući NVO) pokazuju sve veću uključenost u međunarodne pravne poslove. Uzimajući u obzir uticaj koje imaju neke NVO, nameće se zaključak da ove organizacije zaslužuju neki oblik međunarodnopravnog priznanja i konkretnija i efikasnija pravila koja regulišu njihovo delovanje.

Jedan deo teorije neguje otvoren, liberalan pristup o NVO kao subjektima međunarodnog prava, smatrajući da određeni entiteti treba da imaju međunarodnopravni subjektivitet ako imaju prava i/ili obaveze prema tom sistemu. Često se kao primer za ovu tvrdnju navodi davanje određenih prava i obaveza Međunarodnom komitetu Crvenog krsta prema odredbama Ženevskih konvencija. Teoretičari koji se zalažu za liberalan pristup regulisanja međunarodnopravnog subjektiviteta NVO polaze od dve grupe argumenata.

Prva grupa argumenata smatra da prava i obaveze nisu dodeljene samo državama i međunarodnim organizacijama, nego i pojedincima i brojnim nedržavnim akterima. Tako je npr. UN Međunarodni komitet za ljudska prava 2000. godine potvrdio obaveznost poštovanja osnovnih ljudskih prava za sve članove društva, što podrazumeva i NVO. ${ }^{49}$ Međunarodni sud pravde u savetodavnom mišljenju o naknadi štete za nastradale funkcionere Ujedinjenih nacija 11. aprila 1949. godine jasno navodi kako „uz države postoje i drugi subjekti međunarodnog prava, koji se po svojim pravima i obavezama mogu razlikovati od država“. ${ }^{50}$

${ }^{49}$ Christine Bakker, Luisa Vierucci, "Introductions: normative or pragmatic definition of NGOs", op. cit., p. 3.

${ }^{50}$ International Court of Justice. Advisory Opinions and orders reparation for injuries suffered in the service of the United Nations advisory opinion of April 11th, 1949. Internet: https:/ / www.icj-cij.org/files/case-related/4/004-19490411ADV-01-00-EN.pdf 16/07/2020. 
Sličan pristup je primenjen i u slučaju pravila UN o odgovornosti države za protivpravne akte iz 2001. godine. Član 33 pomenutog dokumenta razmatra odgovornost države i navodi da „ovaj deo ne dovodi u pitanje nikakvo pravo, koje proizilazi iz međunarodne odgovornosti države, koje se može odnositi direktno na pojedinca ili entitet osim države. “51 Iako ovom odredbom pravni subjektivitet nedržavnih aktera nije izričito priznat, prema stavovima teoretičara, takve tendencije se mogu očekivati u budućnosti. ${ }^{52}$

Druga grupa argumenata se zasniva na činjenici da NVO imaju važnu ulogu u oblikovanju i nastajanju pravila međunarodnog prava, posebno ako se uzima $u$ obzir doprinos koje su ove organizacije dale $u$ pogledu razvoja prava životne sredine i ljudskih prava. Njihov doprinos ka razvoju međunarodnog prava pokazuje da ova oblast nije više ekskluzivni prostor delovanja država. NVO stvaraju nov oblik prava, tzv. „medija pravo“, koje stoji nasuprot prava koje stvara država. Termin „medija pravo“ označava, pre svega, određenu vrstu pritiska na državu i državne organe putem kojih se pravni sistem koriguje i usavršava. U ovom slučaju, NVO zajedno sa određenim društvenim i političkim grupacijama i pojedincima, vrše pritisak na državne organe u pogledu procesa donošenja pravnih pravila, a sve to putem medija. Prema nekim stavovima, kroz njihov uticaj i doprinos u pogledu stvaranja i razvoja međunarodnog prava, NVO imaju de facto svojstvo subjekta međunarodnog prava, ali bez forme kojom bi se to svojstvo uobličilo. $S$ druge strane, njihova uloga u procesu formiranja pravila međunarodnog prava je ograničena, ali se ne može poreći da NVO poseduju „normativni

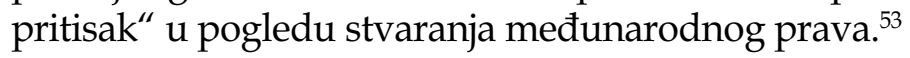

Govoreći o međunarodnopravnom subjektivitetu NVO, jedna grupa autora smatra da je, usled dinamike međunarodnog prava, podela na subjekte i objekte prava zastarela i da u savremenom sistemu postoje

${ }^{51}$ Responsibility of States for Internationally Wrongful Acts 2001. Internet: https://legal.un.org/ilc/texts/instruments/english/draft_articles/9_6_2001.pdf 16/07/2020.

${ }^{52}$ Christine Bakker, Luisa Vierucci, "Introductions: normative or pragmatic definition of NGOs", op. cit., p. 6.

${ }^{53}$ Ibidem, p. 4. 
samo učesnici. Pored država i međunarodnih organizacija, svojstvo aktivnog učesnika u međunarodnom pravu imaju i pojedinci, multinacionalne kompanije i NVO. ${ }^{54}$

Svi ovi pristupi reflektuju dileme savremenog međunarodnog prava. $S$ jedne strane, postoje benefiti koji bi nastali ukoliko bi se postojeća praksa atkivnosti NVO u međunarodnom pravnom poretku regulisala, dok, s druge strane, postoje i određeni rizici u pogledu priznanja pravnog subjektiviteta NVO i ostalim nedržavnim akterima kako bi se očuvala tradicionalana i dominanta uloga države.

Normativno regulisanje položaja NVO razmatrali su Institut za međunarodno pravo i Udruženje za međunarodno pravo. Institut za međunarodno pravo je 1932. godine sačinio nacrt Konvencije o pravnom položaju međunarodnih udruženja. Prema odredbama nacrta, međunarodna udruženja bi morala da se registruju kod stalne komisije, uz podnošenje odgovarajuće dokumentacije. Ukoliko jedna strana uskrati pravni status registrovanom udruženju, prema odredbama nacrta, udruženje bi moglo da se obrati Stalnom sudu međunarodne pravde. Države nisu pokazale mnogo entuzijazma i interesovanja za ovaj nacrt..$^{55}$

Nezaineresovanost država u pogledu pravnog regulisanja položaja NVO pokazala se i 1950. godine, kada je Institut za međunarodno pravo izradio novi nacrt Konvencije o pravnom položaju međunarodnih udruženja. Prema odredbama novog nacrta, države bi trebale da priznaju udruženja na osnovu standarda navedenih u konvenciji, bez prethodnog zahteva za registraciju u okviru jedne države. Određene transnacionalne NVO su vremenom naučile da funkcionišu i bez formalnog priznanja međunarodnopravnog subjektiviteta. Tako je npr. Međunarodni komitet Crvenog krsta potpisao sporazume sa brojim državama, koji omogućuju određene privilegije i imunitete koji se obično daju samo međunarodnim organizacijama. ${ }^{56}$

\footnotetext{
${ }^{54}$ Ibidem, p. 5.

${ }^{55}$ Detaljnije videti kod: Steve Charnovitz, "Nongovernmental Organizations and International Law", op. cit., p. 356.

${ }^{56}$ Ibidem
} 


\section{ZAKLJUČAK}

Nevladine organizacije su se pokazale kao akteri koji su ostvarili veliki uticaj na međunarodno pravo. Bez uticaja NVO međunarodno pravo, ali i međunarodna politika, zasigurno ne bi bili isti. NVO su dale veliki doprinos $\mathrm{u}$ razvoju pojedinih grana prava - međunarodnih ljudskih prava, prava životne sredine, međunarodnog humanitarnog prava itd. Priznanjem njihovog statusa $u$ okviru Društva naroda, a potom dobijanjem statusa konsultanta u okviru Ujedinjenih nacija, udaljile su se od ostalih nedržavnih aktera. Zahvaljujući obimu prava i obaveza koje imaju, NVO se udaljavaju od klasičnog nedržavnog aktera, i po svom statusu bivaju sve sličnije međunarodnim organizacijama.

Činjenica je da se NVO nalaze u međuprostoru. Njihova uloga nije jednaka ulozi objekta međunarodnog prava, ali nije u potpunosti jednaka ni subjektu međunarodnog prava. Elemente međunarodnopravnog subjektiviteta koje poseduju NVO neki autori nazivaju „relativnim subjektivitetom ${ }^{\text {" }}{ }^{57} \mathrm{U}$ ovom pogledu najviše je odmakao Međunarodni komitet Crvenog krsta, NVO koja je praktično sui generis slučaj i koja poseduje najviše elemenata međunarodnopravnog subjektiviteta $u$ odnosu na ostale NVO. Naravno, svi elementi međunarodnopravnog subjektiviteta NVO se moraju ispitati od slučaja do slučaja. Sam pojam NVOje izuzetno širok, a svaka međunarodna NVO ima određeni opseg aktivnosti kojima se bavi. Od aktivnosti međunarodne NVO zavisi i obim njenih prava i obaveza u okviru međunarodnog sistema.

NVO nemaju još uvek jasno regulisan status. Uprkos njihovom značaju, aktivnostima, uključenosti u tokove UN, uticaja koje imaju na međunarodne organizacije i države, ne postoji nijedna konvencija univerzalnog karaktera koja reguliše njihov položaj. Neregulisanjem položaja NVO imaju veliki manevarski prostor, te deluju u svim oblastima u kojima njihovo delovanje nije izričito zabranjeno.

NVO su značajne i na unutrašnjem i na međunarodnom nivou. $\mathrm{Na}$ unutrašnjem nivou NVO služe kao druga stvarnost, nosioci ideja kojima

${ }^{57}$ Detaljnije videti kod: William Thomas Worster, Relative International Legal Personality Of Non-State Actors, Brooklyn Journal of International Law, Vol. 42, No. 1, 2016, pp. 207-272. 
se koriguje politika države. Na međunarodnom planu aktivnosti NVO su unapredile međunarodno pravo i uticale na tokove svetske politike. Razvojem tehnologije u XXI veku možemo očekivati neke nove oblasti u kojima se uloga NVO može razviti.

Uloga i uticaj koji ostvaruju NVO, ali i drugi nedržavni akteri poput pojedinca, multinacionalnih kompanija itd., pokazuje dinamiku međunarodnog prava i činjenicu da država kao akter polako gubi ekskluzivnost u međunarodnim tokovima. Naravno, ekskluzivnost države kao aktera i subjekta međunarodnog prava nikada neće izbledeti, niti izgubiti na važnosti, ali nam uspešne aktivnosti nedržavnih aktera na međunarodnoj sceni poručuju da je međunarodno pravo dinamična celina i da možemo očekivati brojne nove uloge nedržavnih aktera $u$ promenama koje nauka i tehnologija budu omogućile u XXI veku.

\section{LITERATURA}

Avramov, Smilja, Kreća, Milenko, Međunarodno javno pravo, Naučna knjiga, Beograd, 1986.

Avramov, Smilja, Kreća, Milenko, Međunarodno javno pravo, Savremena administracija, Beograd, 2001.

Bakker, Christine and Vierucci, Luisa "Introductions: normative or pragmatic definition of NGOs", in: Pierre-Marie Dupuy, Luisa Vierucci (ed), NGOs in International Law: Efficiency in Flexibility?, Edward Elgar Publishing, Cheltenham, UK and Northampton, MA. (USA), 2009, pp. 1-20.

Boczek, Boleslav Adam, International Law: A Dictionary, Scarecrow Press, Lanham, Maryland, 2005.

Carter, Barry E., Weiner, Allan S., and Hollis, Duncan B., International Law, Walters Kulwer, New York, 2018.

Charnovitz, Steve, Nongovernmental Organizations and International Law, The American Journal of International Law, Vol. 100, No. 2 (Apr., 2006), pp. 348-372.

Convention on the International Institute of Agriculture, Convention signed at Rome June 7, 1905. 
Cullen, Holly and Morrow, Karen, "International civil society in international law: The growth of NGO participation", Non-State Actors \& International Law, No. 1, Vol. 1, 2001, pp. 7-39.

Danilović, Nemanja, „Međunarodne organizacije i njihova uloga subjekata međunarodnog prava“, Megatrend Revija, Vol. 16, No. 2, 2019, pp. 95-114.

Davies, Thomas, "The Historical Development of NGOs", in: Aynsley Kellow, Hannah Murphy- Gregory (eds), Handbook of Researsh on NGOS, Edward Elgar Publishes, Chelthenham UK, Northampton, MA, USA, 2018, pp. 15-34.

Dzehtsiarou, Kanstansin, European Consensus and the Legitimacy of the European Court of Human Rights, Cambridge University Press, Cambridge, 2015.

Fitzduff, Mari and Church, Cheyanne, "Stepping up to the table: NGOs Strategies for Influencing policy on conflics issues", in: Mari Fitzduff, Cheyanne Church (eds), NGOs at the Table: Strategies for Influencing Policies in Areas of Conflict, Rowman \& Littlefield Publishers, Landham, MD, 2004, pp. 2-22.

Frigessi di Rattalma, Marco, "NGOs before the European Court of Human Rights: Beyond Amicus Curiae Participation", in: Tullio Treves, Alessandro Fodella et al. (eds), Civil Society, International Courts and Compliance Bodies, Asser Press, The Hague, 2005, pp. 57-67.

Gvozdenović, Ivan, Miladinović, Ines, „Međunarodne nevladine organizacije - fenomen savremenog doba", Vojno delo, br. 4, 2015, str. 75-96.

Lindblom, Anna-Karin, Non-Governmental Organizations in International Law, Cambridge University Press, New York, 2006.

Nijman, Janne E., "Non-state actors and the international rule of law: revisiting the 'realist theory' ofinternational legal personality", in: Math Noortmann and Cedric Ryngaert (Eds), Non-state actor dynamics in international law: from law-takers to law-makers, Routledge, London and New York, 2010, pp. 91-124. 
Martens, Kerstin, "Examining the (Non-)Status of NGOs in International Law", Indiana Journal of Global Legal Studies, Vol. 10, Issue 2, 2003, pp. 1-25.

Paunović, Žarko, Nevladine organizacije - Potreba ili zavera, Demokratska stranka/Istraživačko izdavački centar, Beograd, 2007.

Paunović, Žarko, „Neprofitne organizacije - prilog pojmovnom razjašnjenju“ , FPN, Godišnjak, br. 6, 2011, str. 251-262.

Pellicciari, Igor, "Feeding the Trojan horse: International aid policies in support to NGOs (1990-2015)", in: Raffaele Marchetti (ed.), Partnership in International Policy-Making, Palgrave Macmillan, London, 2017, pp. 293-313, p. 309.

Tarlock, A. Dan, “The Role of Non-Governmental Organizations in the Development of International Environmental Law", Chicago-Kent Law Review, Vol. 68, Issue 1, 1992, pp. 61-76.

Taylor, Prue, An Ecological Approach to International Law: Responding to the Challenges of climate change, Routledge, London and New York, 1998. Wapner, Paul, "Civil Society”, in: Thomas G. Weiss, Sam Daws (eds), The Oxford Handbook on the United Nations, Oxford University Press, Oxford, 2007, pp. 254-264.

Woodward, Barbara K., The Role of International NGOs: An Introduction, Willamette Journal of International Law and Dispute Resolution, Vol. 19, Issue 2 (2011), pp. 203-231.

Worster, William Thomas, Relative International Legal Personality Of Non-State Actors, Brooklyn Journal of International Law, Vol. 42, No. 1, 2016, pp. 207-272.

\section{Internet izvori}

Convention for the protection of the marine environment of the NorthEast Atlantic. Internet: https:/ / www.ospar.org/site/assets/files/ 1290/ospar_convention_e_updated_text_in_2007_no_revs.pdf

Convention on access to information, public participation in decisionmaking and access to justice in environmental matters. Internet: 
https://www.unece.org/fileadmin/DAM/env/pp/documents/ce p43e.pdf

ECOSOC Resolution 1996/31 Consultative Relationship between the United Nations and non-governmental organizations. Internet: https://www.un.org/esa/coordination/ngo/Resolution_1996_31/i ndex.htm

International Court of Justice. Advisory Opinions and orders reparation for injuries suffered in the service of the United Nations Advisory Opinion of April 11th, 1949. Internet: https:/ / www.icj-cij.org/files/ case-related/4/004-19490411-ADV-01-00-EN.pdf

Responsibility of States for Internationally Wrongful Acts 2001. Internet: https://legal.un.org/ilc/texts/instruments/english/draft_articles/9 _6_2001.pdf

Rebasti Emanuele and Vierucci, Luisa, "Legal Status for NGOs in Contemporary International Law?", The paper don the outcomes of the Workshop on 'A Legal Status for NGOs in Contemporary International Law? A Contribution to the Debate on "Non-State Actors" and Public International Law at the Beginning of the TwentyFirst Century', pp. 1-19. Internet: https:/ / esil-sedi.eu/wp-content /uploads/2018/04/VierucciRebasti-1.pdf

The Covenant of the League of Nations (Including Amendments adopted to December, 1924) Internet: https://avalon.law.yale.edu/ 20th_century/leagcov.asp

United Nations Conference on Environment \& Development Rio de Janerio, Brazil, 3 to 14 June 1992 AGENDA 21. Internet: https://sustainabledevelopment.un.org/content/documents/Agen da21.pdf 


\section{LEGAL STATUS OF NGOS IN INTERNATIONAL LAW}

Abstract: The paper examines theoretical dilemmas regarding the legal status of NGOs, their historical development as well as their position within the United Nations and their impact on international law. Traditionally, NGOs have been considered as objects of international law. Having in mind contributions of NGOs on development of international law and impact on establishment of numerous international institutions, their significance is far beyond the object of international law. NGOs are facing with non regulated position in international law. This fact enables them to act in all aspects of international law and international politics not explicitly prohibited. Despite "terra incognita" legal status, legal personality and influence of some NGOs can be compared with the international legal personality of international organizations. The paper aims to prove that NGOs are moving away from the object of international law and developing some characteristics of the subject of international law.

Keywords: non-governmental organizations (NGOs), legal status, international law, subject of international law, non-state actor, United Nations. 